\title{
SOLID SOLUBILITY OF APATITES IN SILICOPHOSPHATES AND SILICOSULPHATES
}

R.P. GUNAWARDANE

Department of Chemistry, University of Peradeniya, Peradeniya.

(Date of receipt : 15 January 1993)

(Date of acceptance : 02 July 1993)

\begin{abstract}
Two distinct phases containing phosphorus, silicon and sulphur occur in cement clinker and rhenania fertilizer. These are solid solutions based on two structural types: apatite (phosphate apatites and ellestedites) and silicocarnotite (silicocarnotite and silicosulphate) structures. Ellestedites, $\mathrm{Ca}_{10}\left(\mathrm{SiO}_{4}\right)_{3}\left(\mathrm{SO}_{4}\right)_{3} \mathrm{Z}_{2}$, and apatites, $\mathrm{Ca}_{10}\left(\mathrm{PO}_{4}\right)_{6} \mathrm{Z}_{2}(\mathrm{Z}=\mathrm{F}, \mathrm{Cl}$ or $\mathrm{OH})$ are completely miscible as are silicocarnotite, $\mathrm{Ca}_{10}\left(\mathrm{SiO}_{4}\right)_{2}\left(\mathrm{PO}_{4}\right)_{4}$, and silicosulphate, $\mathrm{Ca}_{10}\left(\mathrm{SiO}_{4}\right)_{4}\left(\mathrm{SO}_{4}\right)_{2}$. The silicocarnotite, however, shows limited solid solubility with apatites. Ternary phase diagrams constructed for the systems fluorapatite - chlorapatite - silicocarnotite, fluorapatite - chlorapatite - silicosulphate, fluorellestedite - chlorellestedite silicocarnotite and fluorellestedite - chlorellestedite - silicosulphate show that they all have three distinct phase regions. These are apatite solid solution, silicocarnotite solid solution and a two phase region containing the two solid solutions. The extent of solubility is different in the four systems. A noteworthy feature is that ellestedites form extensive halogen-deficient solid solutions with silicosulphate at $900-1100^{\circ} \mathrm{C}$. In all cases the solid solution may be envisaged by substitution of $\mathrm{P}^{+5}$ by equal number of $\mathrm{Si}^{+4}$ and $\mathrm{S}^{+6}$ in tetrahedral positions $\left(2 \mathrm{P}^{+5} \longrightarrow \mathrm{Si}^{+4}+\mathrm{S}^{+6}\right)$. The results are important for understanding the thermal behaviour of industrially important materials containing $\mathrm{P}, \mathrm{Si}$ and $\mathrm{S}$.
\end{abstract}

Key words: Solid solution, apatite, ellestedite, silicophosphate, silicosulphate.

\section{INTRODUCTION}

Apatites are chemically and industrially important materials. Apatite structure ${ }^{1}$ is fairly stable under varying conditions and is adopted by many chemically similar phases. Related silicon and sulphur containing phases such as silicosulphate and silicocarnotite have been widely reported ${ }^{2}$ to occur in cement clinker and in rhenania fertilizer ${ }^{3}$ made from apatite.

Two structural types may be recognized among these compounds with apatite and silicocarnotite structures. Crystal data for these phases are summarized in Table 1. Natural and synthetic apatites containing $\mathrm{P}, \mathrm{Si}$ and $\mathrm{S}$ have the general formula $\mathrm{Ca}_{10}\left(\mathrm{XO}_{4}\right)_{6} \mathrm{Z}$ : typically, $\mathrm{X}=\mathrm{P}$ or $(\mathrm{Si}+\mathrm{S})$ and $\mathrm{Z}=\mathrm{F}, \mathrm{Cl}$ or $\mathrm{OH}$. Apatites, $\mathrm{Ca}_{10}\left(\mathrm{PO}_{4}\right)_{6} \mathrm{Z}_{2}$ and ellastedites, $\mathrm{Ca}_{10}\left(\mathrm{SiO}_{4}\right)_{3}\left(\mathrm{SO}_{4}\right)_{3} \mathrm{Z}_{2}$ are examples of this series. Silicocarnotite, $\mathrm{Ca}_{5}\left(\mathrm{SiO}_{4}\right)\left(\mathrm{PO}_{4}\right)_{2}$ and silicosulphate, $\mathrm{Ca}_{5}\left(\mathrm{SiO}_{4}\right)_{2} \mathrm{SO}_{4}$ are believed to be isostructural.

It is generally assumed that all apatite members are completely miscible and that the silicocarnotite members are also completely miscible. However there has been no 
systematic study of the solid solubility of apatites in silicocarnotite type phases. The extent of solid solubility of haloapatites in silicocarnotite and silicosulphate in the temperature range $900-1100^{\circ} \mathrm{C}$ was determined in the present investigation. The results are important for understanding the thermal behaviour of industrially important materials containing tetrahedral phosphorus, silicon and sulphur.

Table 1: Crystal data for apatites and silicocarnotites.

\begin{tabular}{|c|c|c|c|}
\hline Name & Formula & Crystal System & $\begin{array}{c}\text { Unit Cell } \\
\text { Dimensions }\left(A^{0}\right)\end{array}$ \\
\hline Fluorapatite $^{1}$ & $\mathrm{Ca}_{10}\left(\mathrm{PO}_{4}\right)_{6} \mathrm{~F}_{2}$ & & $\underline{\mathrm{a}}=9.371, \underline{\mathrm{c}}=6.885$ \\
\hline Chlorapatite $^{1}$ & $\mathrm{Ca}_{10}\left(\mathrm{PO}_{4}\right)_{6} \mathrm{Cl}_{2}$ & & $\overline{\mathrm{a}}=9.629, \underline{\mathrm{c}}=6.776$ \\
\hline Hydroxyapatite ${ }^{1}$ & $\mathrm{Ca}_{10}\left(\mathrm{PO}_{4}\right)_{5}(\mathrm{OH})_{2}$ & Hexagonal & $\underline{\mathrm{a}}=9.422, \underline{\mathrm{c}}=6.883$ \\
\hline $\begin{array}{l}\text { Mineral apatite } \\
\text { (Eppawela) }\end{array}$ & $\mathrm{Ca}_{10}\left(\mathrm{PO}_{4}\right)_{6}(\mathrm{Cl}, \mathrm{F})_{2}$ & $\mathrm{P} 6_{3} / \mathrm{m}$ & $\underline{\mathrm{a}}=9.470, \underline{\mathrm{c}}=6.863$ \\
\hline Oxyapatite 5 & $\mathrm{Ca}_{10}\left(\mathrm{PO}_{4}\right)_{6} \mathrm{O}$ & & $\underline{\mathrm{a}}=9.474, \underline{\mathrm{c}}=6.889$ \\
\hline Fluorellestedite 6 & $\mathrm{Ca}_{10}\left(\mathrm{SiO}_{4}\right)_{3}\left(\mathrm{SO}_{4}\right)_{3} \mathrm{~F}_{2}$ & & $\underline{\mathrm{a}}=9.540, \underline{\mathrm{c}}=6.990$ \\
\hline Chlorellestedite & $\mathrm{Ca}_{10}\left(\mathrm{SiO}_{4}\right)_{3}\left(\mathrm{SO}_{4}\right)_{3} \mathrm{Cl}_{2}$ & Hexagonal & \\
\hline Hydroxyellestedite & $\mathrm{Ca}_{10}\left(\mathrm{SiO}_{4}\right)_{3}\left(\mathrm{SO}_{4}\right)_{3}(\mathrm{OH})_{2}$ & $\mathrm{P} 63 / \mathrm{m}$ & \\
\hline $\begin{array}{l}\text { Mineral } \\
\text { Ellestedite }^{7}\end{array}$ & $\mathrm{Ca}_{10}\left(\mathrm{SiO}_{4}\right)_{3}\left(\mathrm{SO}_{4}\right)_{3}(\mathrm{~F}, \mathrm{Cl}, \mathrm{OH})_{2}$ & & $\underline{\mathrm{a}}=9.491, \underline{\mathrm{c}}=6.921$ \\
\hline Silicocarnotite $^{8}$ & $\mathrm{Ca}_{10}\left(\mathrm{SiO}_{4}\right)_{2}\left(\mathrm{PO}_{4}\right)_{4}$ & & $\begin{array}{l}\underline{\mathrm{a}}=6.737 \\
\underline{\mathrm{b}}=15.508 \\
\underline{\mathrm{c}}=10.132\end{array}$ \\
\hline Silicosulphate $^{9}$ & $\mathrm{Ca}_{10}\left(\mathrm{SiO}_{4}\right)_{4}\left(\mathrm{SO}_{4}\right)_{2}$ & $\begin{array}{l}\text { Orthorhom- } \\
\text { bic, Pnma }\end{array}$ & $\begin{array}{l}\underline{\mathrm{a}}=6.852 \\
\underline{\mathrm{b}}=15.408 \\
\underline{\mathrm{c}}=10.183\end{array}$ \\
\hline
\end{tabular}

\section{METHODS AND MATERIALS}

Starting materials were Analar grade dried $\mathrm{CaCO}_{3}, \mathrm{CaF}_{2}, \mathrm{CaCl}_{2}, \mathrm{Ca}_{3}\left(\mathrm{PO}_{4}\right)_{2}, \mathrm{CaSO}_{4}$ and very pure (99.9\%) powdered quartz. $\mathrm{CaSiO}_{4}$ was made by firing Analar calcium carbonate and quartz. Apatites, $\mathrm{Ca}_{10}\left(\mathrm{PO}_{4}\right)_{6} \mathrm{~F}_{2}$ and $\mathrm{Ca}_{10}\left(\mathrm{PO}_{4}\right)_{6} \mathrm{Cl}_{2}$; ellestedites, $\mathrm{Ca}_{10}\left(\mathrm{SiO}_{4}\right)_{3}\left(\mathrm{SO}_{4}\right)_{3} \mathrm{~F}_{2}$ and $\mathrm{Ca}_{10}\left(\mathrm{SiO}_{4}\right)_{3}\left(\mathrm{SO}_{4}\right)_{3} \mathrm{Cl}_{2}$; silicocarnotite $\mathrm{Ca}_{5}\left(\mathrm{SiO}_{4}\right)\left(\mathrm{PO}_{4}\right)_{2}$ and silicosulphate, $\mathrm{Ca}_{5}\left(\mathrm{SiO}_{4}\right)_{2}\left(\mathrm{SO}_{4}\right)$ phases were synthesized using the above starting materials in the temperature range $1000-1200^{\circ} \mathrm{C}$ in platinum crucibles. These end members as well as original starting materials were used to establish subsolidus phase equilibria. The compositions were made up by mixing relevant staring materials in appropriate molar ratios in an agate mortar. Compositions were mixed thoroughly by making a paste with acetone and allowed to dry. The batches were then kept in platinum foil envelopes and fired in a muffle furnace until equilibrium was attained ( $12 \mathrm{~h}-3 \mathrm{~d})$. After firing the products were quenched in air. 
The products were then examined by powder X-ray diffraction using a Hagg Guinier camera with $\mathrm{Cu} \mathrm{K}_{\alpha}$ radiation. In most cases pure samples of the end members were synthesized and their $\mathrm{X}$-ray powder patterns were taken as standard patterns after verification. X-ray powder patterns of the heat-treated products were compared with the standard powder patterns on an illuminated screen for rapid identification. Representative samples were also examined under a polarizing microscope to confirm the absence of any melts or glass after firing.

\section{RESULTS}

Preliminary experiments disclosed that solid solution between fluorapatite chlorapatite, haloapatite - hydroxyapatite and fluorellestedite - chlorellestedite are essentially complete. Variation of unit cell dimension, $\underline{a}$, with substitution of $\mathrm{F}$ or $\mathrm{OH}$ by $\mathrm{Cl}$ in apatites has also been studied in the solid solution series. The results are shown in Figure 1. Continuous increase of $\underline{a}$ axis is observed with substitution of $\mathrm{F} / \mathrm{OH}$ by $\mathrm{Cl}$.

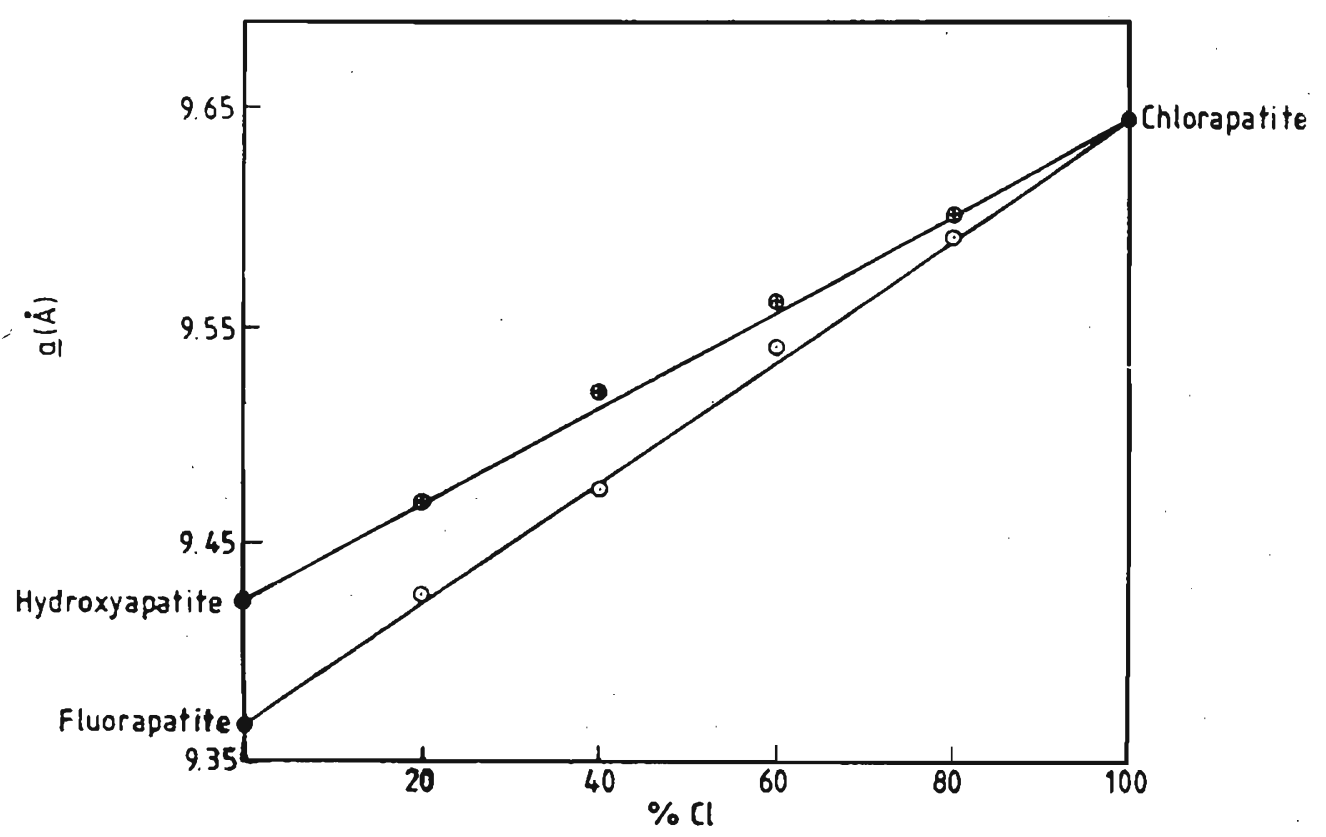

Figure 1: Variation of unit cell dimension a (in $\mathrm{A}^{9}$ ) with substitution of $\mathrm{F} / \mathrm{OH}$ by $\mathrm{Cl}$ in apatiles.

The silicocarnotite join was also found to be binary with complete solid solubility across the join. With this information heating experiments were conducted on the following ternary systems at $1100^{\circ} \mathrm{C}$. 
1. Fluorapatite(FAp)-chlorapatite(ClAp)-silicocarnotite(Sc).

2. Fluorapatite-chlorapatite-silicosulphate(Ssul).

3. Fluorellestedite(FElls)-chlorellestedite(CIElls)-silicocarnotite.

4. Fluorellestedite-clorellestedite-silicosulphate.

The results of these heating experiments are summarized in Table 2.

Table 2: Results of selected heating experiments at $1100^{\circ} \mathrm{C}$.

\begin{tabular}{|c|c|c|c|c|}
\hline & Compo & sition & Phases Presents & \\
\hline FAp & CLAp & - Sc System & & \\
\hline 20.0 & 74.0 & 6.0 & Ap s.s & \\
\hline 80.0 & 10.0 & 10.0 & Ap s.s & \\
\hline 40.0 & 40.0 & 20.0 & Ap s.s + Sc s.s & \\
\hline 30.0 & 20.0 & 50.0 & Ap s.s + Sc s.s & \\
\hline 10.0 & 10.0 & 80.0 & Ap s.s + Sc s.s & \\
\hline 4.0 & 3.0 & 93.0 & Sc s.s & \\
\hline FAp & ClAp & Ssul System & & \\
\hline 20.0 & 74.0 & 6.0 & Ap s.s & \\
\hline 80.0 & 10.0 & 10.0 & Ap s.s. & \\
\hline 40.0 & 40.0 & 20.0 & Ap s.s + Ssul s.s & \\
\hline 30.0 & 20.0 & 50.0 & Ap s.s + Ssul s.s & \\
\hline 10.0 & 10.0 & 80.0 & Ap s.s + Ssul s.s & \\
\hline 4.0 & 3.0 & 93.0 & Ssul s.s & \\
\hline FElls & ClElls & Sc System & & \\
\hline 60.0 & 30.0 & 10.0 & Ells s.s & \\
\hline 40.0 & 40.0 & 20.0 & Ells s.s & \\
\hline 30.0 & 30.0 & 40.0 & Ells s.s + Sc s.s & \\
\hline 20.0 & 20.0 & 60.0 & Ells s.s + Sc s.s & \\
\hline 10.0 & 10.0 & 80.0 & Ells s.s + Sc s.s & \\
\hline 5.0 & 5.0 & 90.0 & Sc s.s & \\
\hline FElls & ClElls & Ssul System & & \\
\hline 40.0 & 50.0 & 10.0 & Ells s.s & \\
\hline 30.0 & 40.0 & 30.0 & Ells s.s & \\
\hline 30.0 & 20.0 & 50.0 & Ells s.s & \\
\hline 20.0 & 20.0 & 60.0 & Ells s.s + Ssul s.s & \\
\hline 10.0 & 10.0 & 80.0 & Ells s.s + Ssul s.s & \\
\hline 5.0 & 5.0 & 90.0 & Ssul s.s & \\
\hline
\end{tabular}

FAp - Fluorapatite ; ClAp - Chlorapatite ; FElls - Fluorellestedite ; ClElls - Chlorellestedite ; Sc - Silicocarnotite ; Ssul - Silicosulphate ; s.s. - Solid solution. 
On the basis of these results phase diagrams were constructed for the above mentioned 4 ternary systems at $1100^{\circ} \mathrm{C}$.

\section{Fluorapatite-chlorapatite-silicocarnotite system}

Figure 2 shows the phase diagram constructed for the system at $1100^{\circ} \mathrm{C}$. A complete series of solid solution was observed on the FAp-ClAp binary join while limited solid solubility was observed along the other two binary joins with silicocarnotite. The plane shown (Fig. 2) is a true ternary system at subsolidus temperatures and contains 3 distinct regions. Two of these are small fields: one of homogeneous silicocarnotite, the other of apatite solid solution. It also contains a large phase region in which the two solid solutions coexist.

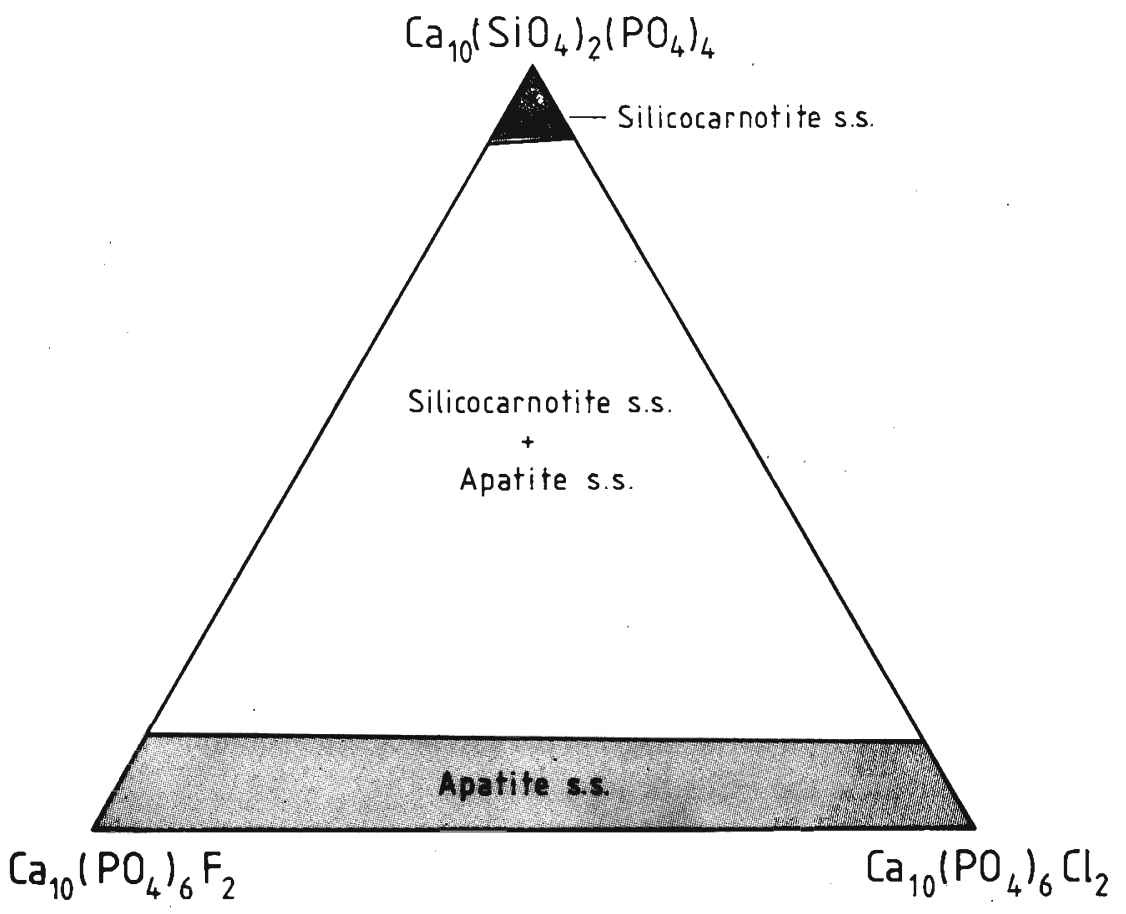

Figure 2: The ternary system (in mol \%) of nuorapatite-chlorapatite-silicocarnotite at $1100^{\circ} \mathrm{C}$.

Fluorapatite-chlorapatite-silicosulphate system

The results are shown in Figure 3. The diagram is very similar to Figure 2 . In this system too limited solid solubility was observed between apatite and silicosulphate. Silicosulphate s.s. and apatite s.s. regions are rather narrow with conspicuous and very large two-phase region in the centre. 


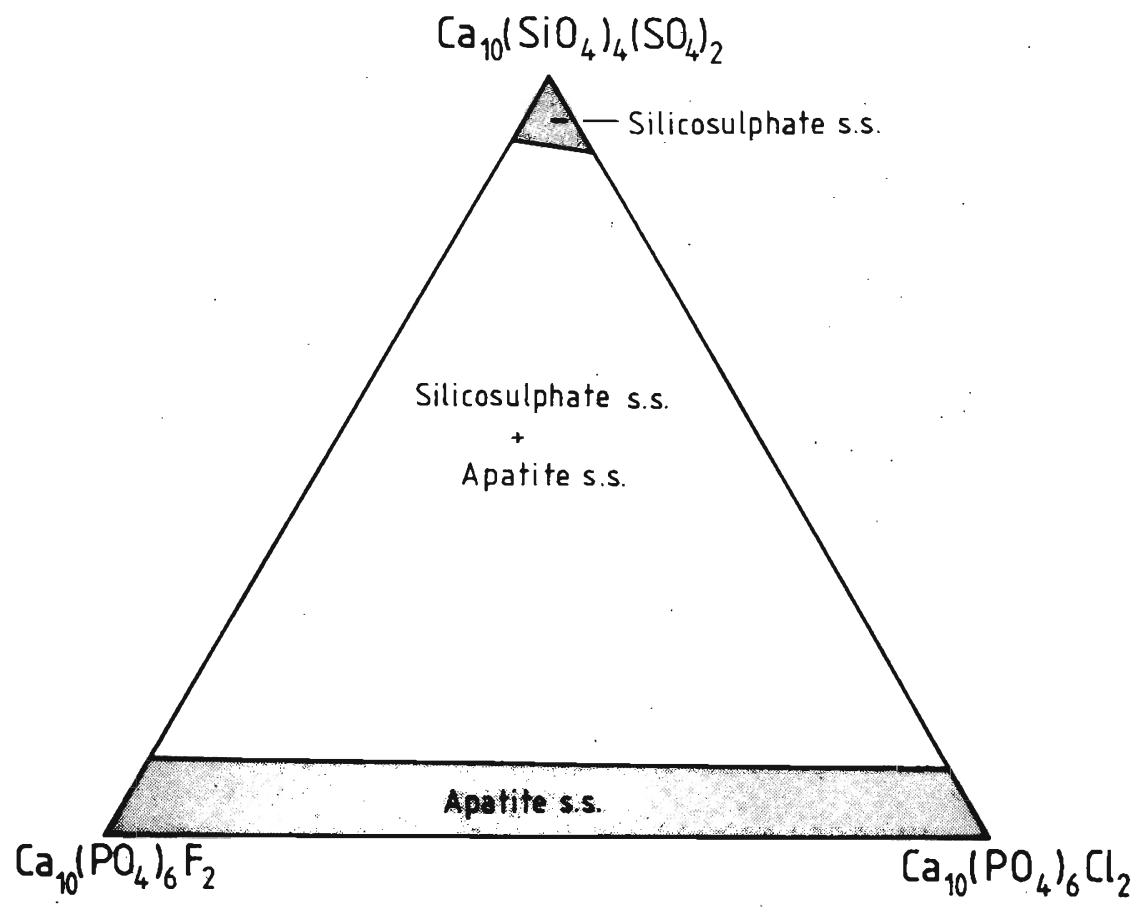

Figure 3: The ternary system (in mol \%) of fuorapatite-chlorapatite-silicosulphate at $1100^{\circ} \mathrm{C}$.

\section{Fluorellestedite-chlorellestedite-silicocarnotite system}

Fluorellestedite and chlorellestedite were found to be completely miscible while the joins involving silicocarnotite had partial solid solubility at both ends. The ternary phase equilibrium diagram (Fig. 4) shows three distinct regions: a very narrow region of silicocarnotite s.s. and a large region of ellestedite s.s. and a much larger two-phase region in between. As shown in the diagram the extent of solid solubility along ClElls-Sc is more extensive than in the FElls-Sc join.

\section{Fluorellestedite-chlorellestedite-silicosulphate system}

This system includes the compositions of the two halogen $\mathrm{Si}-\mathrm{S}$ apatites and silicosulphate. Figure 5 shows the results of this study. Although silicosulphate and ellestedite are not completely miscible, appreciable solid solubility exists at both ends of this binary join. This plane is also a true ternary system at subsolidus temperatures. It also has 3 distinct regions as in the previous cases. The most significant difference is the presence of an extensive field of single-phase ellestedite (apatite type) solid solutions. These extend to $50-60 \%$ mol silicosulphate, which is the most extensive apatite based ternary solid solution observed in the present study. 


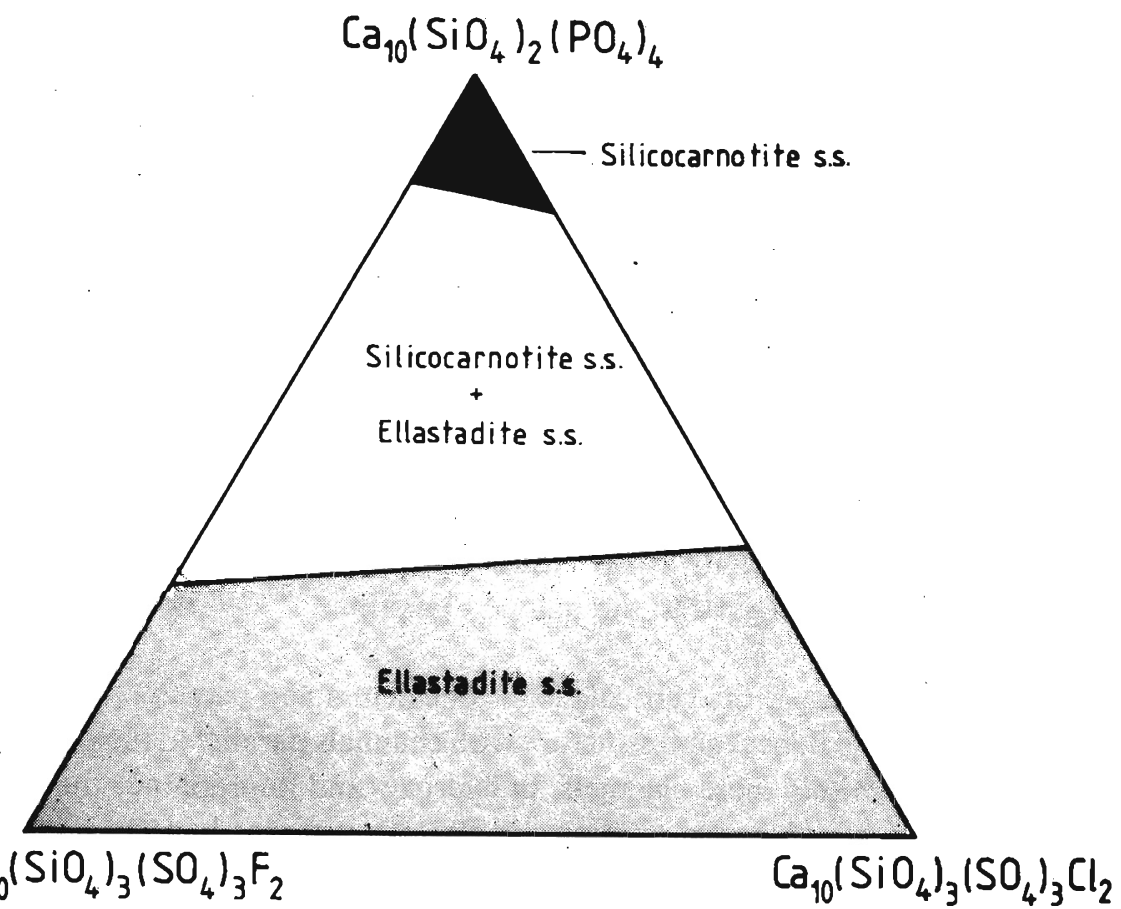

Figure 4: The ternary system (in mol \%) of nuorellestedile-chlorellestedite-silicocarnotite at $1100^{\circ} \mathrm{C}$.

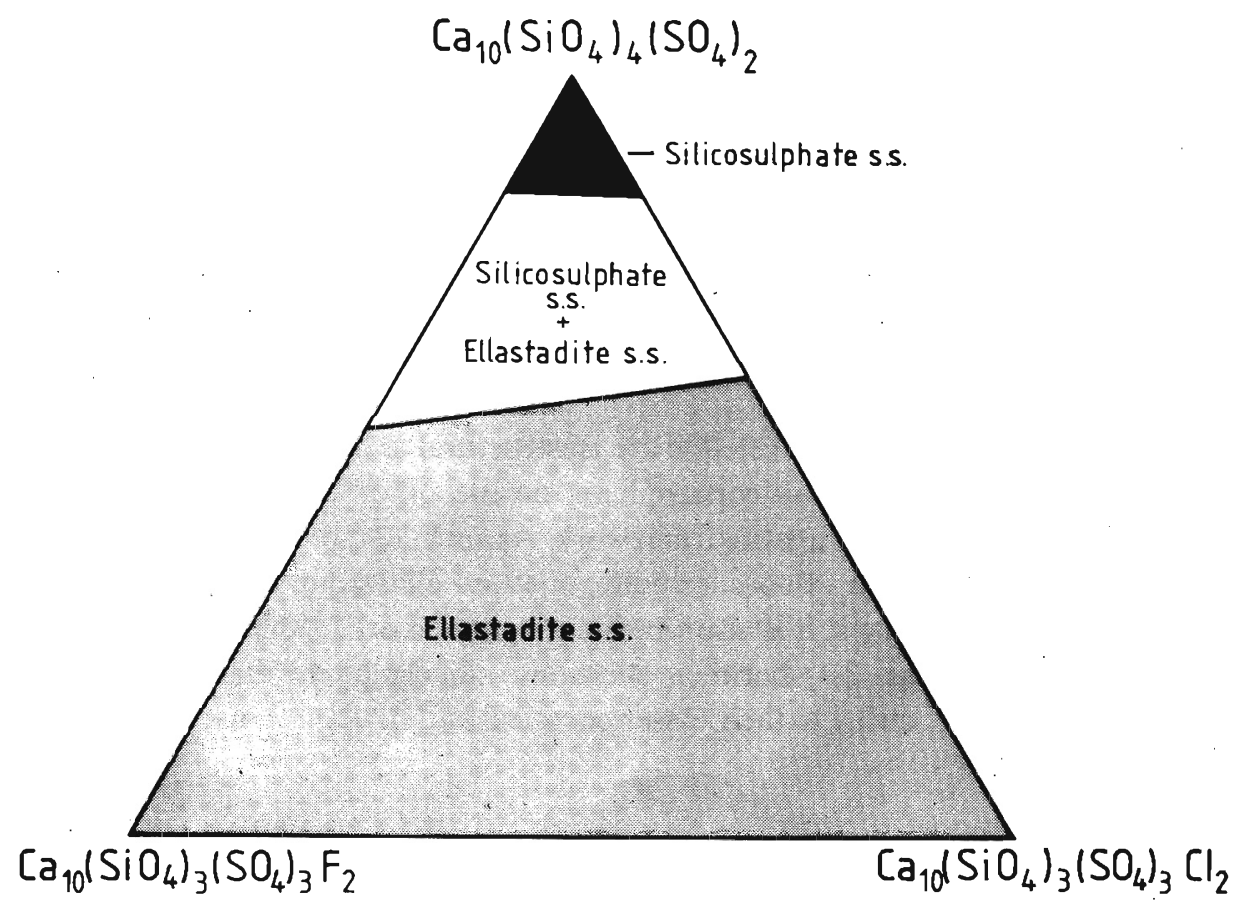

Figure 5: The ternary system (in mol \%) of nuorellestedite-chlorellestedite-sislicosulphate at $1100^{\circ} \mathrm{C}$. 
Some selected compositions representing each of the systems mentioned above were annealed again at $900^{\circ} \mathrm{C}$ for 6 days to see whether exsolution occurred. No changes were observed in the $\mathrm{X}$-ray powder patterns after this heat treatment indicating that the limits of solid solution remained essentially unaltered event at $900^{\circ} \mathrm{C}$. Therefore, it seems likely that the observed ranges of apatite solid solution are a feature of these phase diagrams over a wide range of temperatures.

\section{DISCUSSION}

The study demonstrates that there is a complete series of solid solution between fluorapatite and hydroxyapatite as well as between fluorapatite and chlorapatite. Although it appears that the three phases are isostructural, in fact only fluorapatite and hydroxyapatite are strictly isostructural. ${ }^{10}$ Chlorapatite structure is different from the other two with regard to the halogen positions. ${ }^{10}$

In the apatite structure the vertical chains of calcium and oxygen atoms are linked by $\mathrm{XO}_{4}$ groups to form honeycomb structure with channels parallel to the $\underline{\mathrm{c}}$ axis. Halide ions are positioned within these channels. In hydroxy- and fluorapatites the $\mathrm{OH}$ and $\mathrm{F}$ are situated on mirror planes at (001/4) and (003/4), whereas in chlorapatite the $\mathrm{Cl}$ atoms are at $(000)$ and $(001 / 2)$ positions which are relatively large sites. Since the distances between two sets of sites are not large enough to accommodate halogens at both sites, the occurrence of complete series of solid solutions between fluor-and chlorapatites cannot be explained using a direct replacement mechanism.

Crystal structure investigation of a natural fluorchlorapatite ${ }^{11}$ has revealed that the solid solution in fluorchlorapatite is achieved by a $0.4 \mathrm{~A}^{0}$ shift of the $\mathrm{Cl}$ atoms along $\underline{\mathrm{c}}$ axis, relative to its position in end-member chlorapatite. It has also been suggested from $\mathrm{X}$-ray data ${ }^{12}$ that fluorchlorapatite is made possible by creation of new $\mathrm{F}$ sites in the anion column, which yields reasonable Cl-F distances. Therefore, it appears that the solid solution mechanism in this case is rather complex and involves either shifting of existing $\mathrm{Cl}$ sites or creation of new $\mathrm{F} / \mathrm{OH}$ sites to reduce any strain in the structure.

Chlorellestedite and fluorellestedite are isostructural and they too have the apatite structure. Silicocarnotite and silicophosphate, on the other hand, have a somewhat different structure related to apatite framework. As such, complete solubility has been observed in chlorellestedite - fluorellestedite, apatite - ellestedite and silicocarnotite silicosulphate binary systems. It is also worth noting that more extended solid solubility has been observed (Figs. 2-4) between ellestedite-silicosulphate than in the case of apatite-silicocarnotite, owing to their closer chemical and structural resemblance in the former case. 
Apatite-ellestedite solid solution series is formed by the replacement of $\mathrm{P}^{+5}$ in $\mathrm{PO}_{4}^{-3}$ groups by equal number of $\mathrm{Si}^{+4}$ and $\mathrm{S}^{+6}$ as shown below:

$$
\begin{gathered}
\mathrm{Ca}_{10}\left(\mathrm{PO}_{4}\right)_{6} \mathrm{Z}_{2} \longrightarrow \mathrm{Ca}_{10}\left(\mathrm{SiO}_{4}\right)_{3}\left(\mathrm{SO}_{4}\right)_{3} \mathrm{Z}_{2} \\
6 \mathrm{P}^{+5} \longrightarrow 3 \mathrm{Si}^{+4}+3 \mathrm{~S}^{+6}
\end{gathered}
$$

Similarly, silicocarnotite-silicosulphate solid solution series may be visualized as follows:

$$
\begin{array}{r}
\mathrm{Ca}_{5}\left(\mathrm{PO}_{4}\right)_{2}\left(\mathrm{SiO}_{4}\right) \longrightarrow \mathrm{Ca}_{5}\left(\mathrm{SiO}_{4}\right)_{2}\left(\mathrm{SO}_{4}\right) \\
2 \mathrm{P}^{+5} \longrightarrow \mathrm{Si}^{+4}+\mathrm{S}^{+6}
\end{array}
$$

Solid solutions between apatite and a halogen-free phase such as silicosulphate implies the existence of apatites deficient in halogen relative to the ideal formula. Thus, it can be seen that the solid solutions extending from ellestedite towards silicosulphate must therefore have the general formula,

$$
\mathrm{Ca}_{10}\left(\mathrm{SiO}_{4}\right)_{3+x}\left(\mathrm{SO}_{4}\right)_{3-x} \quad \mathrm{Z}_{2-2 x} \square_{2 x}
$$

\section{( $\square$ represent halogen vacancies)}

This solid solution series containing vacant halogen sites is rather extensive with $\mathbf{x}$ reaching up to about 1.3 (Fig. 5). This is not unusual : halogen deficient apatites in which halogens are replaced by $\mathrm{O}^{2-}$ have been reported. ${ }^{13}$ Recent structure determination of an oxyapatite ${ }^{\mathbf{5}, 14}$ has confirmed its widespread occurrence. However, in this solid solution series no extra oxygens are needed to achieve a charge balance. Therefore, this solid solution series represents a novel group of halogen deficient calcium apatites.

\section{References}

1. Corbridge D.E.C. (1974). The Structural Chemistry of Phosphorus pp. 106-117. Elsevier Scientific Publishing Co., Amsterdam.

2. Pliego-Cuervo Y. \& Glasser F.P. (1978). Phase relations in silicocarnotite solid solutions. Cement and Concrete Research 8 : 519-524.

3. Gunawardane R.P. \& Glasser F.P. (1979). Reaction of chlorapatite with sodium carbonate and silica. Joumal of Materials Science 14 : 2797-2810.

4. Gunawardane R.P. (1987). Studies on chlorine and fluorine in Eppawela apatite. Joumal of the National Science Council of Sri Lanka 15(1) : 87-99. 
5. Pryce M.W. (1972). Crystal structure of oxyapatite. Mineral Magazine 38:968-972.

6. Dihn V.P. \& Klement R. (1942). Structure and properties of ellestedites. Zeits Elektrochemie 48: 331-338.

7. Harada K., Nagashima K ., Nakao K. \& Kato A . (1971). Studies on mineral ellestedite. American Mineralogist 56: 1507-1511.

8. Dickens B. \& Brown W.E. (1971). Crystal chemistry of silicophosphates. Tschermaks Mineralogie Petrographie Mitterand 16:1-27.

9. Brasseur H. \& Dallemagne M.J. (1949). Crystal data of calcium oxyapatite. Bulletin Society Chemie France 2: D125-126.

10. Mehmel M. (1930). Structure and crystal chemistry of apatites. Zeits Kristallographie 75 : 323-339.

11. Hughes J.M., John M., Cameron M. \& Crowley K.D. (1990). Crystal structures of natural ternary apatites. American Mineralogist 75(3-4) : 295-301.

12. Mackie P.E. \& Young R.A. (1974). Crystal structure of haloapatites. Journal of Solid State Chemistry 11 : 319-321.

13. McConnell D. (1973). Apatite its crystal chemistry, mineralogy, utilization and geological and biological occurrences, Applied Mineralogy 5, Springer-verlag, Vienna and New York.

14. Gunawardane R. P., Howie, R.A. \& Glasser F.P. (1982). Structure of oxyapatite, $\mathrm{NaY}_{9}\left(\mathrm{SiO}_{4}\right)_{6} \mathrm{O}_{2}$. Acta Crystallographica $\mathrm{B38}:$ 1564-1566. 